\title{
FACTORS INFLUENCING CHANGES OF BEEF CATTLE HERD QUANTITY AND SIZE: CASE OF LATVIA
}

Andra ZVIRBULE, Faculty of Forestry, Faculty of Economics and Social Development, Latvia Agriculture University, Liela iela 2 , Jelgava, Latvia; andra.zvirbule@1lu.lv (corresponding author)

Raivis ANDERSONS, Faculty of Forestry, Faculty of Economics and Social Development, Latvia Agriculture University, Liela iela 2, Jelgava, Latvia; raivis andersons@inbox.lv

Beef production volumes in Latvia have been different over a long period of time, beef output growth has been noted, as well as its sharp decrease, so it is important to analyze, what are the most important factors that are affecting beef production volumes, that will give an idea of the possibilities for beef market regulation. Consequently, the study objective can be defined: Identify factors affecting beef production in Latvia.

For this research statistical methods, correlation analysis, induction, deduction, analysis and synthesis were used. These methods gave an accurate picture of factors that are affecting beef production volumes.

According to the results, it can be concluded that beef production volumes are significantly affected by such factors as demand for beef. The results of this research indicate that Latvia beef production volumes are affected by the market demand. As an essential factor for increasing the number of beef cattle in Latvia, export opportunities are available where increasing amount of fresh or chilled beef exported in EUR is increasing the number of suckler cows, where there is a close positive relationship $(r=0.76)$, which indicates an increase in demand from Latvian meat beef holding output. The quality of the soil in the region and climatic conditions will affect the specialization of farms. The largest number of bovine animals is grown in regions of Vidzeme and Latgale, where average cereal production is lowest per hectare. Pierīga and Zemgale regions have high crop yields on average per hectare, so in this region the number of bovine animals is the smallest.

Keywords: beef demand, subsidies, beef export, agriculture

\section{INTRODUCTION}

In Latvia climatic conditions are appropriate for cattle breeding. There are land resources that are too wet, they are located on steep slopes or they are too sandy to be processed. In this case, these areas can be used for forest cultivation or cultivation and use for green mass grazing and grazing in extensive farming. Therefore the use of land resources, that would otherwise not be profitable for intensive crop production or would be too unmanageable, will be encouraged.

To understand exactly what motivates farmers to focus on breeding beef cattle, it is necessary to analyze factors that are affecting cattle number growth.

Aim: Identify the most important factors influencing the number increase of beef cattle and beef cattle herds.

Object: Beef cattle farms in Latvia

Subject: Factors influencing the production volumes of beef cattle farms.

Tasks: 1 . Study theoretical aspects of factors influencing production volumes of cattle farms.

2. Analyze factors influencing production volumes of beef cattle farms.

\section{MATERIALS AND METHODS}

The study covers a period from 2004 to 2016. There were used graphical method, correlation analysis, induction, deduction, analysis and synthesis.

Information for the research where gathered from Agricultural Data Center (ADC), Rural Support Service (SAD) and Central Statistical Bureau of Latvia (CSB).

Restrictions: Information from the ADC on the number of beef breeds of bovine animals from 2004 to 2007 was not available.

\section{FACTORS INFLUENCING THE CULTIVATION OF MEAT CATTLE - THEORETICAL ASPECTS}

Substantial changes in agriculture resulted from the collapse of the USSR, which meant the need to restructure agricultural production, adapt existing production to new conditions and market economy conditions. It was necessary to 
review production processes, achieved levels of yield, livestock genetics and other factors affecting the international competitiveness of post-communist countries (Scrieciu, 2011). Farmers were faced with a situation where they themselves had to decide what, how and how much to produce to make a profit. The society is interested in economic activities in the countryside, because the viability of farms is important from the point of view of rural development - whether agricultural land and settlements will be used. Abandoned areas of agricultural land cause losses - loss of revenue from the production of agricultural products and later expenditure, returning overgrown agricultural land to agriculture (Bojnec, et al, 2013).

It is important that interest in the processing of agricultural land is also from people living in rural areas, especially those who have access to agricultural land resources. When assessing support options and stimulating the processing of agricultural land, it is important to know the wishes of landowners regarding land use, which could be affected by legislation, landowner knowledge, education, experience and quality of land resources in order to be able to predict the impact on rural development, employment in countryside and preservation of environment. When assessing the willingness of landowners to use their land resources, their level of knowledge and management objectives, which could be affected by regulatory enactments, should be taken into account. When purchasing property, buyers take into account factors such as the fertility of the land, the area of land in hectares, the current use of land and the distance from the strategic points of economic activity. Land user decision on land use is influenced by land fertility, relief, potential value by selling it (Schouten, et al, 2014). Considering peculiarities of the most important resource of agricultural production, agricultural land, owners had to assess the possible uses of land, as it significantly affects the usefulness of the use of production resources.

In the course of economic activity, the farm must be competitive - it must be able to produce agricultural production at the lowest possible cost and sell produced goods at the highest possible price. In order to create a competitive farm, it was necessary to evaluate the factors of the external and internal environment that could promote or hinder the development of the beef cattle breeding industry. As a first factor influencing the farm's decision to engage in the production of a specific agricultural product is the availability of financing for development, the ability to invest in production development (Knootz, 2010). The entrance in beef cattle farming sector is less investment demanding, as is the case, for example, in dairy farming.

Agricultural companies, like other companies, are looking for ways to increase their profits - this can be done either by increasing the sale price of the output or by reducing production costs. Both options are relatively limited - this can be achieved by new production technologies, livestock or crop varieties that are much less demanding with higher yield potential.

This forces agricultural enterprises to concentrate on those areas of activity that give them the most profits with the least costs that can be done with the resources at their disposal (Bezat-Jarzębowska, et. al. 2013). Decision-making at livestock farms is based on product development, including strategic goals related to reducing biological and market risks, preserving food safety, using family labor, reducing overall costs, improving production conditions and efficiency by investing (French, et al. 2011). The restructuring and adaptation of production to market demand also had to consider the possibilities of the farm to produce competitive agricultural products. When selecting the specialty of the farm, farm managers had to consider the climatic conditions and resources at their disposal for the preparation of high quality fodder. Very significant backwardness was observed in crop production, with great influence on climatic conditions and the use of crop varieties and production technologies (Scrieciu, 2011). With poor quality crop production, milk cattle for quality milk cannot be maintained without additional costs for the purchase of feed, which increases the cost of milk production. Therefore, in areas with low fertility rates, most often choose to deal with livestock farming, the most common in extensive farm management system. This is also borne out by studies by the European Union where the region of climatic conditions in Europe has been affected by the growing breeding technology in cattle breeding in Europe. More extensive farming practices based on the grazing system for meat cattle fattening are being applied in the north Europe (The meat sector in the European Union, 2004).

In the transition to a market economy, farms that chose to grow beef were to modernize and adapt to market conditions in order to achieve good production results. Compared to developed countries, labor productivity, task sharing opportunities and possibilities to adapt to new production conditions were considerably lower, considering the level of technological development, the existing material base and the opportunities for development in agriculture in European Union member states (Scrieciu, 2011). After changes of production conditions and the process of adaptation, increase production of beef cattle is facilitated by the development of specialization. A free market that is not saturated creates a situation where the specialization of beef cattle breeding can be developed.

This creates preconditions for price differentiation between bovine meat produced in southern and northern Europe. Considering resources invested and the time consumed for beef production in northern Europe compared to southern Europe, it is the basis for a higher sale price of beef produced in northern Europe.

Sales prices may affect the demand for beef, which in turn can have a significant impact on production volumes, considering the difference in demand and supply. Global trends show that overall meat production structure and beef production have rapidly and consistently declined over the last twenty years. Such tendencies can also be attributed to the structure of meat consumption (Popluga, et al, 2010). This points to restructuring of global market and the escalation of competition for the rest of the market. Demand for beef affects its production volumes, which requires manufacturers to be able to compete with the lowest possible price or new products. New consumer trends focus on vegetarianism, healthy lifestyles, reduced consumption of meat in general (Knootz, 2010). The tendency of such consumers to consume less meat is also indicated by a study carried out in Latvia confirming that consumption of beef is not a significant precondition for domestic consumption: majority of consumers surveyed do not like beef smell and taste, which suggests that in 
comparison with pork, beef is a relatively new product on the Latvian consumer menu. Similarly, the relatively low prices and lack of information on beef recipes can be considered as limiting factors for beef consumption (Popluga, et al, 2010). A cheaper supply of dairy cattle in market makes a significant pressure on beef prices. Great advantage of dairy cattle is that it includes not only milk extraction, but also relatively cheaper beef production, both from culled dairy cows and from bulls and culled heifers.

The pressure of milk quotas on production limits was the result of the availability of a large number of relatively cheap milk beef on the market, which is also classified as beef. This situation also reduced selling prices of meat from bovine meat breeding, resulting in a disadvantage - relatively expensive fodder and low beef sale prices. It affected specialty beef cattle farms - both higher production costs and competition for feed.

It can be concluded that market for meat beef and milk beef interacts with each other - competition is created, where meat from cattle breeds yield qualitative and relatively expensive meat, while comparatively cheap meat is obtained from dairy cattle, since bulls and culled cows and heifers in dairy farming are considered to be by-products (Kempen, et al, 2011). Such market situation does not contribute to development of beef cattle specialization, since beef cattle is the only product that can be sold to beef cattle farms.

A subsidy mechanism has been introduced to help producers cope with losses incurred in beef production (Aby, et al, 2012) to promote production, compensate for losses incurred during development period of the industry. It ensures that farms have additional developmental resources to promote competitiveness. For example, direct payments to Dutch farmers are intended to encourage farmers to implement a minimum level of management of animal welfare, environmental protection and sustainability (Samson, et al, 2013). It ensures that the farm, while promoting its competitiveness, will also comply with environmentally-friendly requirements and provide the conditions necessary for animal well-being.

The development is gradual, therefore, to a large extent, beef cattle farms in Europe are affected by subsidies that help farms to generate income from economic activity, since the cost of raising beef cattle is higher than the proceeds from sale of meat. In current market situation, to replace subsidy revenues, farms will have to increase sales prices for beef, which is unlikely because of the alternative supply of beef from dairy cattle (Amores, et al, 2009).

Meat cattle breeding is stimulated by various support payments, objectives of which are:

- Reduction in intervention prices for slaughtered cattle and special payment for beef.

- To increase revenues of farms whose main activity is the raising of beef cattle (suckler cow payment).

- Motivating Extensive Management (Extensive Growing Supplement).

- Market equilibrium, reducing seasonal effects on sales volumes and prices.

- Allow national governments to implement specific farming methods and set up a special payment envelope for a variety of unforeseen events.

In 2003, the EU decided that payments would no longer be tied to production - farmers were given opportunity to produce what the market demanded. When switching to the new scheme, a large part of the EU countries remained in system when it supports specialization of beef cattle breeding.

In order to promote sales of beef cattle, it was working with consumers to increase demand for beef production in EU. To achieve this, the following activities were implemented:

- Beef labeling to ensure traceability.

- Identification of animals to prove cattle belonging to a specific holding.

- Improved lists of authorized feeds and increased control.

- Stricter controls on imported beef.

- EU-funded beef sales promotion measures (Norton, 2005).

Stimulation of this kind of production can help to develop the meat industry and increase both the number of herds and the production of beef.

\section{FACTORS INFLUENCING BEEF PRODUCTION IN LATVIA}

When analyzing the impact of internal consumption on increase in production of beef, it can be concluded that, taking into account changes in population, when in 2017, compared with 2004, according to CSB (Central Statistical Bureau of Latvia) ISG021, according to data of "Permanent population by gender at beginning of year", population of Latvia has decreased by 326 thousand people.

Retail prices for beef and veal purchases by households tend to increase, when compared to price of beef in 2004, 2.23 euros per kilogram, more than doubled in 2016, reaching price of 4.95 euros per kilogram.

When analyzing consumption volumes of bovine meat and the impact of price on consumption (see Figure 1), it can be concluded that there is a close negative correlation $(\mathrm{r}=-0.935)$ between price of beef and veal and the consumption of beef and veal. Determination coefficient $\mathrm{R}^{2}=0.87$ suggests that the price of beef and veal in $87 \%$ of all cases will be the deciding factor for how many kilograms of beef and veal will be bought. 


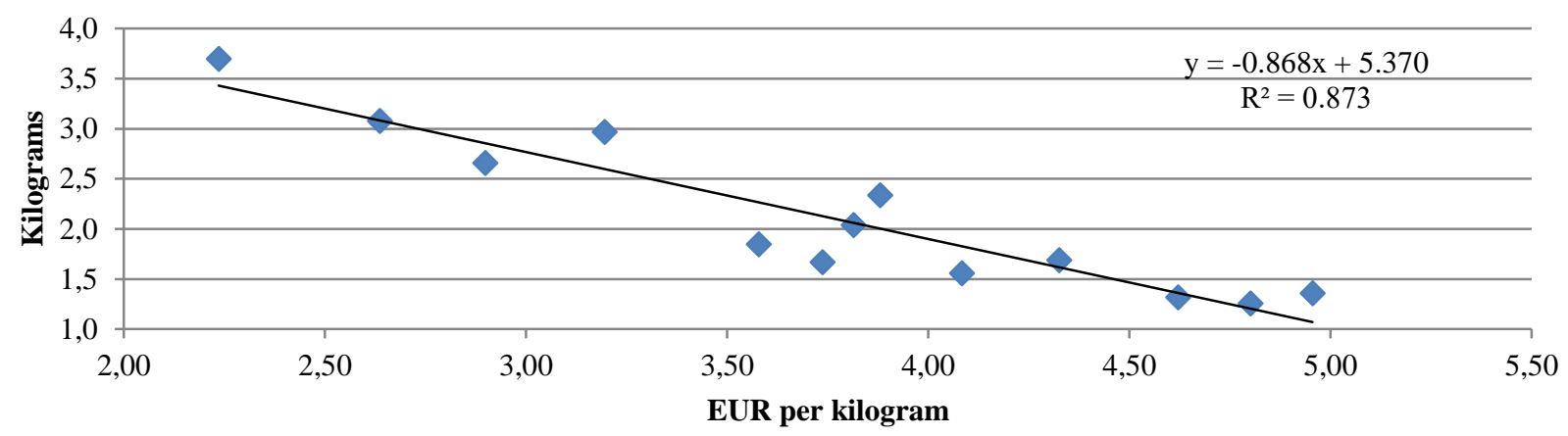

Source: author calculated according to CSB data MBG15.

Figure 1 . The consumption of beef and veal on average per household member correlated with average purchase price of a kilogram of beef and veal in Latvia in a period from 2004 to 2016

Taking into account the domestic dependence of domestic beef consumption on sale price, it also affects the amount of beef produced when it contracted during country's economic recession and continued to decrease until 2012 (see Figure 2). Volume of beef produced is increasing from 2014 - on average $6 \%$ against previous year.

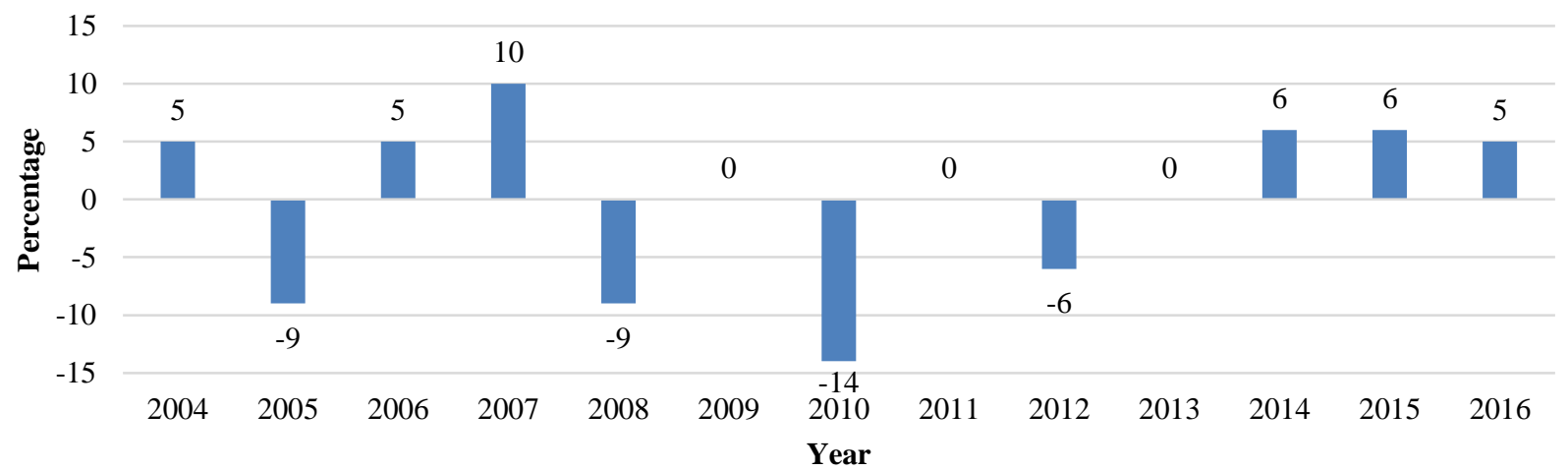

Source: author calculated according to CSB data LIG011.

Figure 2. Beef production dynamics in Latvia during a period from 2004 till 2016.

In Latvia, on average, about 20 thousand tons of beef are produced each year. Milk produced from dairy cattle is also included here, but in view of changes in structure of dairy cattle, it can be seen that a part of total the beef production is also provided by dairy cattle, but tendency is that the increase is mainly related to increase in number of beef cattle, which contributes to increase in production of beef.

With decline in domestic consumption, support for national and EU investments, which allows farms to reduce losses resulting from unfavorable market conditions, are very important for farms. One of the most important forms of support for production is state aid for suckler cows originally intended for development of a herd to ensure maximum productive and predictable production of beef (see Figure 3). After 2010, farms no longer have access to aid for suckler cows that are pure bovine animals.

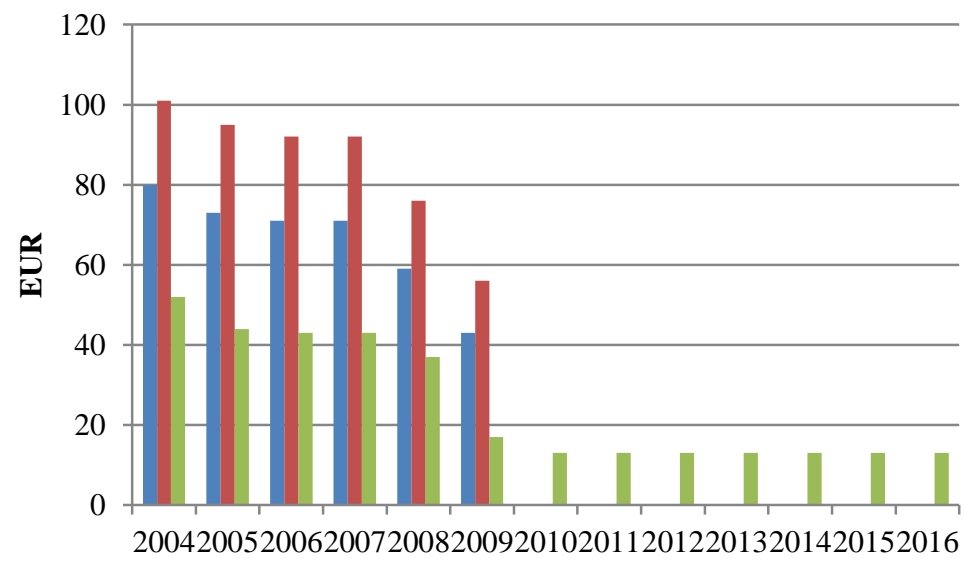

Support payments for pure-bred suckler cows

- Support payments to farmers for the purpose of cultivation of pure-bred sucler cows

Support payments for suckler cows

Year

Source: Rural Support Service (SAD) statistics for a period from 2004 till 2016

Figure 3. Type and amount of support payments for suckler cows in Latvia for a period from 2004 to 2016. 
With the decline in state support, the number of suckler cows in the whole of Latvia increased, also during country's recession, where the total number of registered beef cattle after 2007 decreased by 92 herds, reaching previous registered beef cattle herds in 2012 (see figure 4). It was found that the decrease in consumption of domestic beef in Latvia has not affected the number of beef cattle - the number of beef cattle is increasing, which indicates that re are or factors influencing volume of beef production.

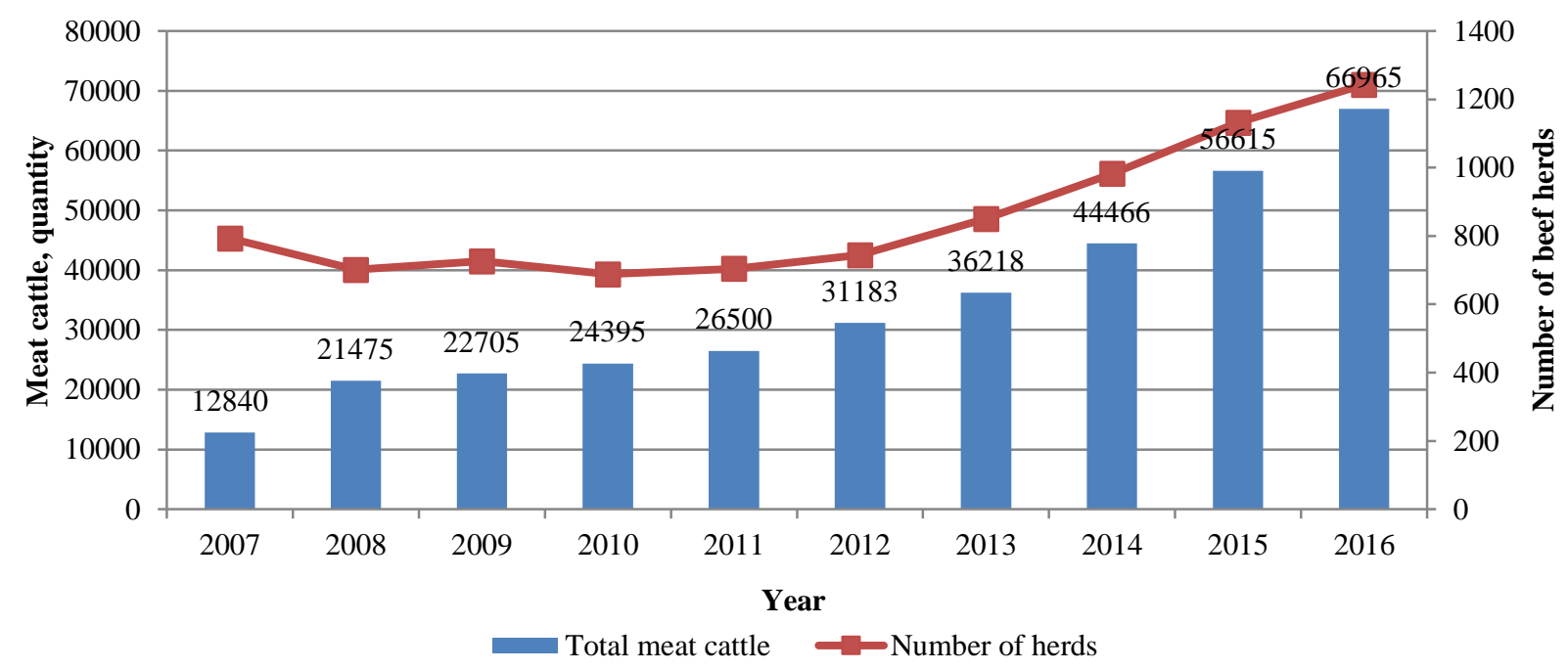

Source: author's calculation based on data from Agricultural Data Center for a period from 2007 till 2016

Figure 4. The number of cattle herds in Latvia in a period from 2004 to 2016 and total number of beef cattle in Latvia during a period from 2007 to 2016.

Data shows that as the number of herds grow, its size also increases - if in 2007 the average stock of livestock was 26.7 bovine animals, then in 2016 there were 54.3 cattle in a herd, which is by $50 \%$ more (see Figure 5). With increase in herd size, proportion of suckler cows will decrease in herds where in $200740 \%$ of all cattle herds had a suckler cow, but in 2016 suckler cow was 43\%. By increasing the number of suckler cows and also the total number of beef cattle, beef cattle farms will be able to produce more beef. And, given the proportion of suckler cows in a herd, it can be concluded that more owners of flocks begin to deal with fattening of beef cattle, which allows farms to sell their produce to the final consumer and consequently also generate higher revenues for farmed animals.

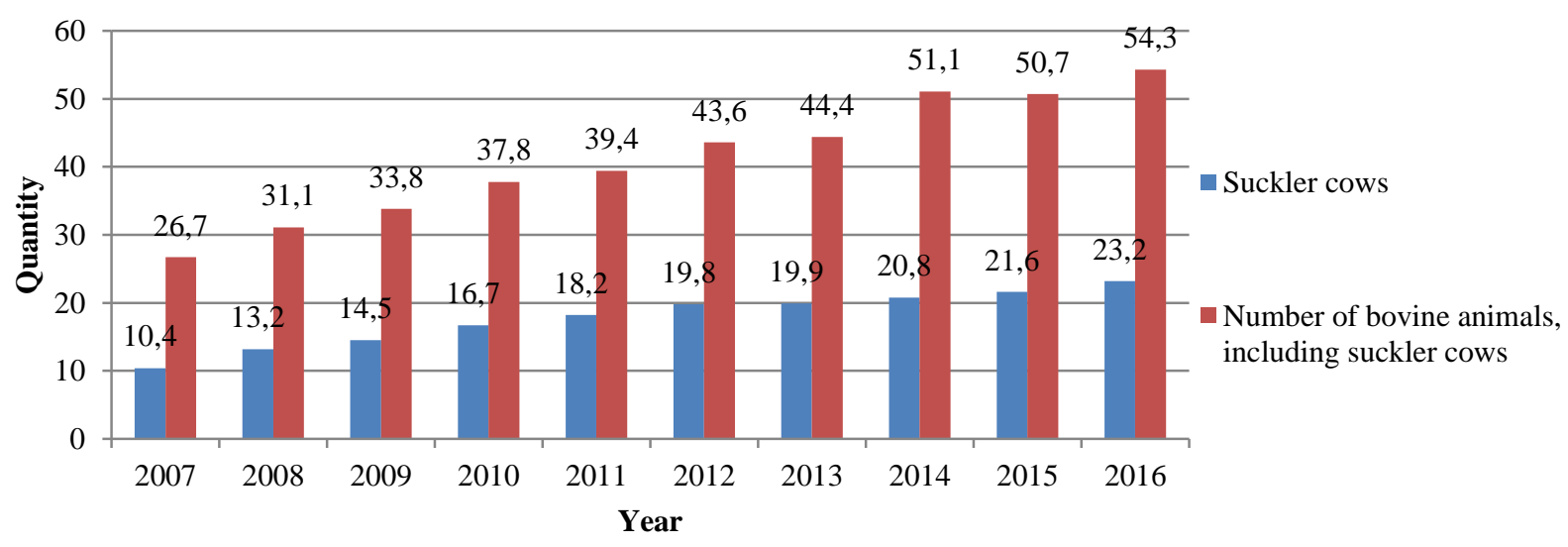

Source: author's calculation based on data from Agricultural Data Center for a period from 2004 till 2016

Figure 5. Average number of female beef and beef cattle in Latvia in a period from 2007 to 2016.

As an essential factor for increasing the number of beef cattle in Latvia, export opportunities are available where increasing amount of fresh or chilled beef exported in EUR is increasing the number of suckler cows, where there is a close positive relationship $(r=0.76)$, which indicates an increase in demand from Latvian meat beef holding output (see Table 1). Increase in the number of suckler cows also has a major impact on export of frozen beef, which has led farmers to increase herds and production volumes in order to be able to meet the demand for the export market. When assessing impact of export volumes on number of livestock, there is no close correlation between export volumes of EUR and number of herds, which indicates that farms of meat cattle specialization are starting to fill this market niche, ensuring demand satisfaction and competitiveness, with possibility of growth. 
Table 1. Correlation coefficients between the number of beef and beef cattle in Latvia and Latvia in period from 2007 to 2016 for exports of bovine products.

\begin{tabular}{|l|l|l|l|}
\hline & Live animals & Meat of bovine animals, fresh or chilled & Meat of bovine animals, frozen \\
\hline Suckler cow & 0.59 & 0.76 & 0.71 \\
\hline Total meat cattle & 0.56 & 0.74 & 0.69 \\
\hline Number of herds & 0.16 & 0.24 & 0.34 \\
\hline
\end{tabular}

Source: author's calculation according to Agricultural Data Center and CSB data, for period from 2007 to 2016

By analyzing the regions impact on the chosen economic activity, it can be concluded that the region has an impact on bovine population. Regions where, on average, according to CSB data, is the lowest crop yield per hectare has the largest number of registered bovine animals. This indicates that the quality of the soil in the region and climatic conditions will affect the specialization of farms. The largest number of bovine animals is grown in regions of Vidzeme and Latgale, where average cereal production is lowest per hectare. Pierīga and Zemgale regions have high crop yields on average per hectare, so in this region the number of bovine animals without milk cows is the smallest.

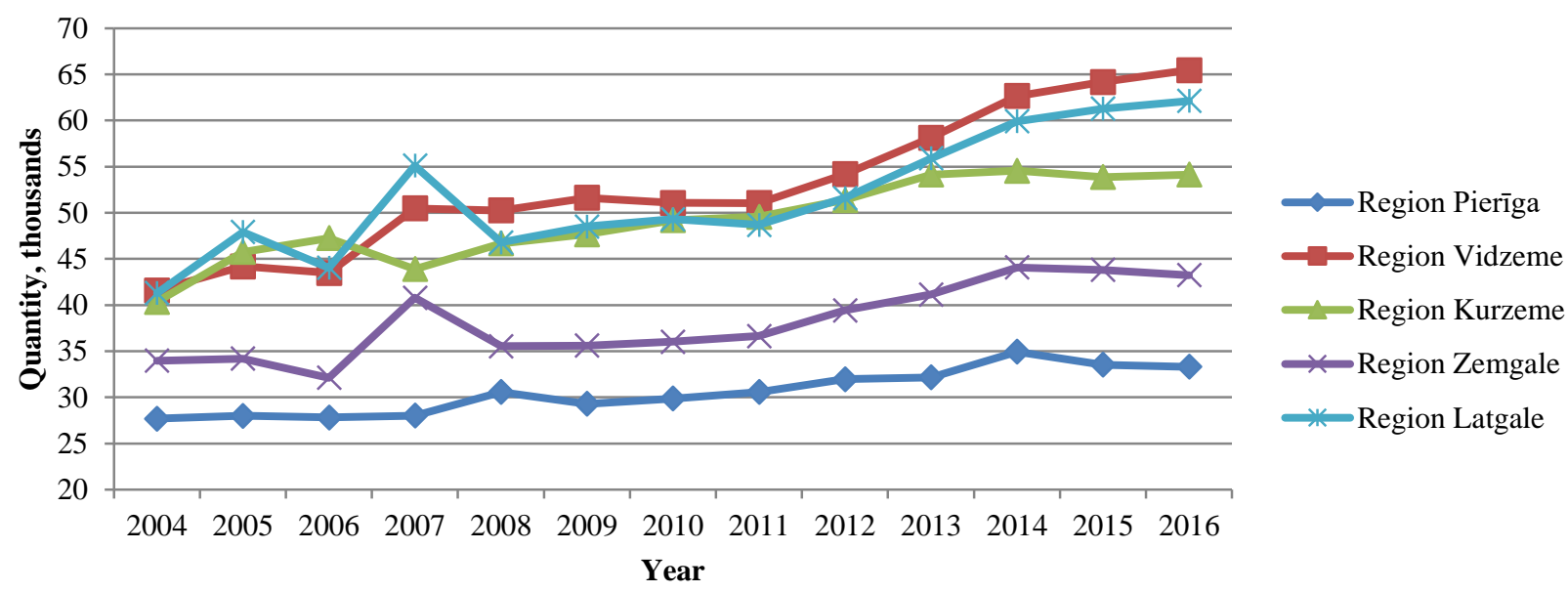

Source: author's calculated according to CSB data LLG0221

Figure 6. Number of cattle in regions of Latvia without milking cows from 2004 to 2016.

When assessing data, it can be concluded that state aid for beef cattle is not considered to be a catalyst for the development of beef cattle herds. Also, the Latvian domestic market does not affect changes in number of beef cattle in the country. Results of this research shows that the main factors contributing to the increase in number of beef cattle and the increase in number of cattle themselves are sales opportunities outside of Latvia - these are export markets where production of beef cattle herds in Latvia can be marketed.

In order to facilitate the development of specialization of beef cattle, it is necessary to work on the development of exports in order to ensure the best possible conditions for the realization of owners of Latvian beef cattle breeders, ensuring a competitive quantity and quality of production.

\section{CONCLUSIONS}

1. In Latvia there is a weak demand for beef, which is flexible, and it changes inversely proportional to changes in beef prices. It can be concluded that there is a close negative correlation $(r=-0.935)$ between price of beef and veal and the consumption of beef and veal. Determination coefficient $\mathrm{R}^{2}=0.87$ suggests that the price of beef and veal in $87 \%$ of all cases will be the deciding factor for how many kilograms of beef and veal will be bought.

2. Growth factor for Latvian beef cattle breeding is export opportunities, where the main products are fresh or chilled beef and frozen beef. Export of live bovine animals over the period considered does not have such a significant effect on increase in the production of beef cattle. Increasing amount of fresh or chilled beef exported in EUR is increasing the number of suckler cows, where there is a close positive relationship $(r=0.76)$

3. Latvian cattle farms become bigger and more competitive, as seen by the increase in the average number of beef cattle in meat cattle holdings. Data shows that as the number of herds grow, its size also increases - if in 2007 the average stock of livestock was 26.7 bovine animals, then in 2016 there were 54.3 cattle in a herd, which is by $50 \%$ more.

4. Support does not play a key role in increasing the beef cattle herds in Latvia. However, the importance of support at the start of the specialization can be assessed as very significant, since special support was paid for the development of livestock genetics that could ensure and predict the quality of beef production.

5. Soil fertility and climatic conditions in the regions of Latvia have an impact on the choice of economic activity of agricultural enterprises. In regions where the smallest crop yields are highest, the number of bovine animals will be the highest as well. The largest number of bovine animals is grown in regions of Vidzeme and Latgale, where average 
cereal production is lowest per hectare. Pierīga and Zemgale regions have high crop yields on average per hectare, so in this region the number of bovine animals is the smallest.

\section{REFERENCES}

1. Åby, B., A., Aass, L., Sehested, E., Vangen, O. 2012. A bio-economic model for calculating economic values of traits for intensive and extensive beef cattle breeds. Livestock Science, No. 143, pp. 259-269. https://doi.org/10.1016/j.livsci.2011.10.003

2. Bezat-Jarzębowska, A., Rembisz, W. 2013. Efficiency-Focused Economic Modeling of Competitiveness In The Agri-Food Sector. Procedia - Social and Behavioral Sciences, No. 81, pp. 359-365. https://doi.org/10.1016/j.sbspro.2013.06.443

3. CSB data LIG011. Manufacture of meat and receivable meat in the slaughter (in carcass weight, thsd tons)

4. CSB data LLG0221. Number of livestock in regions at end of the year.

5. CSB data MBG15. The detailed composition of household consumption expenditure per household member per year (in euro) and MBG16 consumption of food on average per household member per year

6. Kempen, M., Witzke, P., Domínguez, I., P., Jansson, T., Sckokai, P. 2011. Economic and environmental impacts of milk quota reform in Europe. Journal of Policy Modeling, No. 33, pp. 29-52. https://doi.org/10.1016/j.jpolmod.2010.10.007

7. Koontz S., R. 2010. Economic Factors Impacting the Cattle Industry, the Size of the Beef Cow Herd, and Profitability and Sustainability of Cow-Calf Producers. Available at http://www.kla.org/cmdocs/kansasla/library/gipsa/gpdocs1-2883980-v1ncba__appendix_a.pdf (Accessed on 04/01/2016.)

8. Norton, M. 2005. Factors affecting beef and cattle producer prices movements. Monthly Labor Review, Vol. 128, Iss. 5, pp. 32-40.

9. Popluga, D., Špoǵis, K. 2010. Future of Beef Market in Latvia - Consumers Issues and Demand, Production and Taxes. Proceedings of the International Scientific Conference, pp. 22-23, Latvia University of Agriculture

10. SAD statistics for a period from 2004 till 2016 on State aid paid out in sub-program "State Aid for Agriculture and Rural Development (Subsidies)".

11. Samson, G., S., Gardebroek, C., Jongeneel, R., A. 2013. Analysing Dutch dairy farmer behaviour towards the provision of public goods: The added value of an economic simulation experiment. Land Use Policy, No. 34, pp. $321-331$. https://doi.org/10.1016/j.landusepol.2013.04.005

12. Schouten, M., Verwaart, T., Heijman, W. 2014. Comparing two sensitivity analysis approaches for two scenarios with a spatially explicit rural agent-based model. Environmental Modelling and Software, No. 54, pp. 196-210. https://doi.org/10.1016/j.envsoft.2014.01.003

13. Scrieciu, S., S. 2011. Socioeconomic and environmental impacts on agriculture in the new Europe: post-communist transition and accession to the European Union Socioeconomic and environmental impacts on agriculture in the new Europe: post-communist transition and accession to the European Union, $222 \mathrm{pp}$.

14. The meat sector in the European Union (European Commission Directorate-General for Agriculture). Available at http://ec.europa.eu/agriculture/publi/fact/meat/2004_en.pdf (accessed on 02/11/2017.)

15. Wolfova, M., Pribyl, J., Wolf, J., Zahradkova, R. 2006. Effect of subsidy regimes on economic values of functional traits in beef cattle breeding. Journal of Animal Breeding and Genetics, No. 123, pp. 97-104. https://doi.org/10.1111/j.1439-0388.2006.00573.x

16. Gaḷas pārraudzības rezultāti 2016. Available at: http://ldc.gov.lv/upload/doc/resultsbeef16.pdf (Accessed on 09/10/2017) [In Latvian]

17. Gaḷas pārraudzības rezultāti 2015. Available at: http://ldc.gov.lv/upload/doc/resultsbeef15.pdf (Accessed on 09/10/2017) [In Latvian]

18. Gaḷas pārraudzības rezultāti 2014. Available at: http://ldc.gov.lv/upload/doc/resultsbeef14.pdf (Accessed on 09/10/2017) [In Latvian]

19. Gaḷas pārraudzības rezultāti 2013. Available at: http://ldc.gov.lv/upload/doc/resultsbeef13.pdf (Accessed on 09/10/2017) [In Latvian]

20. Gaḷas pārraudzības rezultāti 2012. Available at: http://ldc.gov.lv/upload/doc/resultsbeef12.pdf (Accessed on 09/10/2017) [In Latvian]

21. Gaḷas pārraudzības rezultāti 2011. Available at: http://ldc.gov.lv/upload/doc/resultsbeef11.pdf (Accessed on 09/10/2017) [In Latvian]

22. Gaḷas pārraudzības rezultāti 2010. Available at: http://ldc.gov.lv/upload/doc/resultsbeef10.pdf (Accessed on 09/10/2017) [In Latvian]

23. Gaḷas pārraudzības rezultāti 2009. Available at: http://ldc.gov.lv/upload/doc/resultsbeef2009.pdf (Accessed on 09/10/2017) [In Latvian]

24. Gaḷas pārraudzības rezultāti 2008. Available at: http://ldc.gov.lv/upload/doc/resultsbeef2008.pdf (Accessed on 09/10/2017) [In Latvian]

25. Gaḷas pārraudzības rezultāti 2007. Available at: http://ldc.gov.lv/upload/doc/resultsbeef2007.pdf (Accessed on 09/10/2017) [In Latvian] 